\title{
THE BIOLOGY OF ASTERIAS RUBENS L. III. CAROTENOID PIGMENTS IN THE INTEGUMENT
}

\author{
By H. G. Vevers, M.A., D.Phil. \\ Zoologist at the Plymouth Laboratory
}

In the Plymouth area there is often a marked and consistent difference in coloration of starfishes (Asterias rubens) from different populations. Starfish from populations to the south of Plymouth Breakwater are red-brown or occasionally pale yellow-brown in colour, whereas those from a population living well within Plymouth Sound have been found to be consistently bright red or brick red in colour (Vevers, I949). In the present work analysis has been made of the integumentary carotenoids of dark red-brown A. rubens taken from the trawling grounds between Plymouth Breakwater and the Eddystone.

The asteroids are usually richly coloured, and investigation of a number of species has shown the almost universal occurrence of carotenoid pigments in the integument. In addition to the carotenoids, MacMunn (I886), working at the Plymouth Laboratory, extracted a porphyrin pigment which he identified as haematoporphyrin from the integument of $A$. rubens. It is now known that haematoporphyrin does not occur in nature, and a re-examination of the porphyrin pigments of this species is in course of preparation (Kennedy \& Vevers).

Cuénot (I887) observed that the integument of starfishes consists of three distinct layers: the internal epithelium, which lines the general body cavity and which is not concerned with the external pigmentation of the animal, a median conjunctive layer, in the outer part of which the calcareous plates are deposited, and an external epithelium of tall, elongated cells, covered by a cuticle, through which the cilia protrude. The external epithelial cells with the cuticle make up the epidermis. The majority of the epidermal cells are narrow and columnar, with their inner ends resting on a basement membrane which divides the epidermis from the median conjunctive layer (Ludwig \& Hamann, I899). Scattered among these more generalized epidermal cells are two types of more specialized cells, the mucus gland cells, which are particularly frequent in $A$. rubens, and the mulberry cells, first described by Cuénot (I887) and of unknown function.

Ludwig \& Hamann (I899) stated that, in general, the integumentary pigments of starfishes are deposited in the epidermal layer. Cuénot (I887) found that in Echinaster sepositus a red pigment was deposited in the epidermis, and in the present work it was found that most of the carotenoid pigment of the integument is contained in the unspecialized columnar epithelial cells. There are no special chromatophores. 


\section{Carotenoid Pigments in the Integument}

Abeloos (I926) observed that the carotenoids in the integument of Asterias rubens were sometimes present in the form of complexes produced by the conjugation of a carotenoid with a protein radical. Lönnberg (I93 I, I933, I934) extracted carotenoids from a large number of marine invertebrates, including A. rubens. In most he was able to partition the crude extracts into an epiphase (in petroleum ether) and a hypophase (in $90 \%$ methanol). $\mathrm{He}$ did not, however, use any chromatographic adsorption technique for the separation of the pigments, and in general his results only indicated that at least one and probably two carotenoid pigments were present in the integument of A. rubens.

Von Euler \& Hellström (I934) isolated a carotenoid acid from the aboral integument of $A$.rubens, which they named 'Asterinsäure'. Karrer and Rübel (Karrer \& Jucker, I948, p. 35I) subsequently obtained a yield of astacene from this species, and Karrer \& Jucker (I948, p. 35I) now consider that 'Asterinsäure' is probably identical with astacene (or astaxanthin).

\section{Experimental}

In the present work on the separation of the integumentary carotenoids only dark red-brown specimens of $A$. rubens were used. For analysis by Methods I and 2, aboral integument was finely chopped and ground up with dry acid-washed silver sand (the sand was washed with $\mathrm{HCl}$, and then with three changes of water before being dried). The integument was then extracted with successive portions of acetone, until no further colour appeared in the extract. Petroleum ether (b.p. $40-60^{\circ}$ C.) was added to the acetone extract, and the volume of the whole extract was doubled by addition of distilled water. After gentle shaking, the pigment passed from the acetone-water fraction to the petroleum ether, which was dried by shaking with anhydrous sodium sulphate. The petroleum-ether extract of the total carotenoids was then divided into two parts for further analysis by either Method I or Method 2.

Method I. The petroleum-ether extract was chromatographed on bone meal (B.D.H. bone meal for carotene estimations). Continued elution with petroleum ether removed Fraction I $a$, which was then passed through a column of alumina (B.D.H. aluminium oxide for chromatographic adsorption analysis) on which it formed two bands. The lower band was removed by elution with more petroleum ether and collected separately as Fraction $\mathrm{I} b$, and the upper band, which was the richest in colour, was eluted by petroleum ether containing $5 \%(\mathrm{v} / \mathrm{v})$ of acetone to give Fraction I $c$. The pigment remaining on the bone meal column was eluted by acetone and collected as a pale strawyellow solution (Fraction $\mathrm{I} d$ ).

Fraction $\mathrm{I} b$ was divided into two parts and each was separately evaporated 
almost to dryness over a water-bath, the final traces of liquid being removed in a stream of carbon dioxide. The residues were dissolved in carbon disulphide and petroleum ether respectively. Absorption spectra (Table I) of each of these solutions were recorded with a 'Unicam S.P. 500 Quartz Spectrophotometer'. The absorption maximum obtained for the solution in carbon disulphide is identical with that recorded by Karrer \& Jucker (I948) for $\beta$-carotene. The absorption maximum for the solution in petroleum ether is very close to that obtained for $\beta$-carotene by Morton \& Rosen (I949).

In order to confirm that Fraction $\mathrm{I} b$ was $\beta$-carotene a mixed chromatogram was used. The petroleum-ether solution of the pigment was mixed with a solution of known $\beta$-carotene in the same solvent and the mixture chromatographed on a long column ( $15 \times 1 \mathrm{~cm}$.) of alumina. A single band was formed which did not split on slow elution with petroleum ether.

Table I. Absorption Maxima of Carotenoid Fractions in $M \mu$

$\begin{array}{cccc}\text { Fraction } & \begin{array}{c}\text { Carbon } \\ \text { disulphide }\end{array} & \text { Pyridine } & \begin{array}{c}\text { Petroleum } \\ \text { ether }\end{array} \\ \text { I } b & 485 & - & 449 \\ \text { I } c & 503 & 489 & - \\ 2 b & 485 & - & 449 \\ 2 c & 509 & 497-502 & -\end{array}$

Fraction $\mathrm{I} c$, which was also epiphasic, was divided into two parts, each of which was evaporated to dryness and the residues dissolved in carbon disulphide and pyridine respectively. This fraction gave strong, well-coloured solutions, and spectrophotometer readings gave the absorption maxima recorded in Table I.

These maxima agree very closely with those given by Goodwin \& Srisukh (i949) for esterified astaxanthin. This agreement, together with the fact that Fraction I $c$ was always epiphasic when shaken with a mixture of petroleum ether and $90 \%$ methanol, leaves no doubt that the pigment in this fraction was esterified astaxanthin. It should be noted that the esterified astaxanthin (Fraction $\mathrm{I} c$ ) originally formed part of Fraction $\mathrm{I} a$, which was eluted from the bone-meal column with petroleum ether. This elution is similar to the experience of Morton \& Rosen (I949), who found that esterified 'xanthophyll' was sometimes carried through a bone-meal column with light petroleum.

Fraction I $d$ was collected from the bone-meal column by elution with acetone. It was taken into petroleum ether and partitioned between this solvent and $90 \%$ methanol. The pigment was found to be entirely hypophasic, suggesting the free forms of xanthophylls. From this solution it was taken back into petroleum ether, evaporated to dryness and dissolved in benzene. The benzene solution was chromatographed on zinc carbonate, and a single band formed which was eluted with ether containing $3 \%$ methanol (v/v). The yield from this fraction was never sufficient to give a good sample for spectrophotometric measurement, but its behaviour on phase partition and 
chromatography suggested that it contained one pigment only of the free xanthophyll type, possibly lutein or zeaxanthin.

Method 2. The remainder of the total carotenoid extract was partitioned between petroleum ether and $90 \%$ methanol to give an epiphasic fraction $(2 a)$ and a hypophasic fraction $(2 d)$ respectively. Fraction $2 a$ contained nearly all the pigment. It was evaporated to dryness slowly on a water-bath, the final traces of solvent being removed in a stream of $\mathrm{CO}_{2}$. To the residue were added $2 \mathrm{ml}$. ethanol and $\mathrm{I} \mathrm{ml}$. of $\mathrm{KOH}$ (concentration of $\mathrm{I} 60 \mathrm{~g}$. $\mathrm{KOH}$ in Io6 $\mathrm{ml} . \mathrm{H}_{2} \mathrm{O}$ ), and this saponification mixture was heated and kept just bubbling for $3 \mathrm{~min}$. The residue was cooled by adding distilled water and then extracted with ethyl ether. Some of the pigment passed into the ether but most remained in the lower layer of aqueous ethanolic $\mathrm{KOH}$. On addition of a few drops of glacial acetic acid, followed by gentle shaking, all the pigment passed into the ether. (It is characteristic of astacene that it remains hypophasic in alkaline solution, even in the presence of excess water.) The ether extract was then evaporated to dryness and dissolved in petroleum ether. On addition of an equal volume of $90 \%$ methanol partition took place to give an epiphase (Fraction $2 b$ ) and a hypophase (Fraction 2c).

Fraction $2 b$ was dried over anhydrous sodium sulphate, and chromatographed on a column of alumina. Slow elution with the solvent failed to split the single band of pigment which was finally collected in a flask. This fraction was then examined in the spectrophotometer in $\mathrm{CS}_{2}$ and in petroleum ether, and the maxima recorded were the same as those for $\beta$-carotene in Fraction $\mathrm{I} b$ above.

Fraction $2 c$ was taken from $90 \%$ methanol into petroleum ether, and divided into two parts each of which was evaporated to dryness over a waterbath. The residues were dissolved in $\mathrm{CS}_{2}$ and pyridine respectively and recordings made of the absorption spectra (Table I).

The positions of these maxima (cf. Karrer \& Jucker, I948, p. 242) and the behaviour of this fraction after saponification suggest that the pigment was astacene. Kuhn \& Sörensen (1938) have shown that astacene does not occur naturally, but is produced in the course of saponification by the oxidation of astaxanthin. As the fraction from which the present yield of astacene was derived was originally epiphasic, it is probable that it was present in the integument in the form of esterified astaxanthin. This would agree with the finding of esterified astaxanthin in Fraction $\mathrm{I} c$.

Fraction $2 d$ was very faint in colour. It was treated in the same way as Fraction $\mathrm{I} d$, and behaved the same way on chromatography. It probably represents the small amount of free xanthophyll found in Fraction $\mathrm{I} d$.

As a further check on the identity of the carotenoid pigments, and in order to test for the existence of a carotenoid-protein complex, a third system of extraction was used (Method 3).

Method 3. The integument was ground up with silver sand and extracted 
in the first place with $n$-hexane to remove all the carotenoids which were not bound to a protein. This gave Fraction $3 a$. The residue of tissue was then extracted with acetone to give Fraction $3 b$.

Fraction $3 a$ was relatively pale in colour. By means of phase partition and chromatography it gave weak solutions of $\beta$-carotene, esterified astaxanthin, and a free xanthophyll.

Fraction $3 b$ was strong in colour and contained the greater part of the integumentary carotenoid pigment. It was entirely epiphasic and was found to contain esterified astaxanthin only. There was no evidence that $\beta$-carotene occurred in this fraction.

I am indebted to Dr W. R. G. Atkins, F.R.S., and Dr C. F. A. Pantin, F.R.S., for reading and criticizing the manuscript.

\section{Discussion}

It is probable that the carotenoid pigments extracted from $A$. rubens by Lönnberg were not always fully separated into their constituents prior to spectroscopic determination. The presence of astaxanthin in this species was first noted by Karrer and Rübel. This has been confirmed in the present work, and it has also been found that in the integument it is present in the esterified form. The astaxanthin found in $A$. rubens is very closely comparable with that extracted from the hypodermis of Homarus vulgaris and Nephrops norvegicus by Goodwin \& Srisukh (1949), and there is no doubt that, from the point of view of colour production, it is the most important of the integumentary carotenoids in $A$. rubens. In the dark-brown specimens of $A$. rubens used in the present investigation the greater part of the esterified astaxanthin is linked with a protein. This is similar to the condition found in the carapace and eggs of Astacus gammarus by Kuhn \& Sörensen (1938). Carotenoids have also been extracted from a number of Pacific Coast echinoderms, including four species of asteroids, by Fox \& Scheer (I94I), but the yields were usually from the whole body, and so are not strictly comparable with the present results. They did, however, find that one of the predominant carotenoids in the asteroids was astaxanthin, but they did not record any protein linkage.

\section{SUMMARY}

A preliminary analysis of the integument of dark-brown specimens of Asterias rubens has shown that the carotenoid pigments present are astaxanthin, $\beta$-carotene and a free xanthophyll. The last two occur only in small amounts. The astaxanthin is present in the esterified form, and represents the greater part of the total carotenoids.

Most of the astaxanthin is present in the form of an astaxanthin-protein complex, which is coloured brown or dark brown in the living animal. 


\section{REFERENCES}

Abeloos, M., 1926. Sur les pigments tégumentaires des Astéries. C.R. Soc. Biol., Paris, T. 94, pp. 19-2I.

CuÉnot, L., I887. Contribution à l'étude anatomique des Astérides. Arch. Zool. exp. gén., T. 5, bis suppl., $2^{\mathrm{e}}$ Mém., I44 pp.

EuleR, H. voN \& HellströM, H., I934. Ueber Asterinsäure, eine Carotinoidsäure aus Seesternen. Z. physiol. Chemie, Bd. 223, pp. 89-97.

Fox, D. L. \& SCHEER, B. T., I94I. Comparative studies of the pigments of some Pacific coast echinoderms. Biol. Bull. Woods Hole, Vol. 8o, pp. 44I-53.

Goodwin, T. W. \& SRISUKH, S., I949. Some observations on astaxanthin distribution in marine Crustacea. Biochem. Fourn., Vol. 45, pp. 268-70.

KARRER, P. \& JUCKER, E., I948. Carotinoide. Basel.

KuHN, R. \& SöRENSEN, N. A., 1938. Ueber Astaxanthin und Ovoverdin. Ber. dtsch. chem. Ges., Bd. 7I, p. I879.

LöNNBERG, E., I93I. Untersuchungen über das Vorkommen carotinoider Stoffe bei marinen Evertebraten. Ark. Zool., Bd. 22, A I4, 49 pp.

- 1933. Zur Kenntnis der Carotinoide bei marinen Evertebraten. Ark. Zool., Bd. 25, A I, I7 pp.

— I934. Weitere Beiträge zur Kenntnis der Carotinoide der marinen Evertebraten. Ark. Zool., Bd. 26, A 7, 36 pp.

Ludwig, H. \& Hamann, O., I899. Echinodermen (Stachelhäuter). Die Seesterne. Bronn's Klassen u. Ordnungen des Thierreiches, Bd. 2, Abt. 3, Buch II.

MacMunN, C. A., I886. On the presence of haematoporphyrin in the integument of certain invertebrates. Fourn. Physiol., Vol. 7, pp. 240-52.

Morton, R. A. \& Rosen, D. G., I949. Carotenoids, vitamin A, and 7-dehydrosteroid in the frog (Rana temporaria). Biochem. Fourn., Vol. 45, pp. 612-27.

Vevers, H. G., I949. The biology of Asterias rubens L.: growth and reproduction. fourn. Mar. Biol. Assoc., Vol. 28, pp. 165-87. 